\title{
A Study on Nitrogen Fixing Ability of Soil Isolates and Quantitative Estimation of K Solubilization by Soil and Plant Isolates
}

\author{
Diksha Vishwakarma ${ }^{1^{*}}$, J.K. Thakur ${ }^{2}$ and S.C. Gupta ${ }^{1}$ \\ ${ }^{1}$ Rajmata Vijayaraje Scindia Krishi Vishwa Vidayalaya, Gwalior, RAK College of Agriculture, \\ Sehore, (Madhya Pradesh) 466 001, India \\ ${ }^{2}$ Division of Soil Biology, ICAR-Indian Institute of Soil Science, Bhopal - 462038 , \\ Madhya Pradesh, India \\ *Corresponding author
}

\begin{tabular}{|c|c|}
\hline & A B S T R A C T \\
\hline & \multirow{5}{*}{ 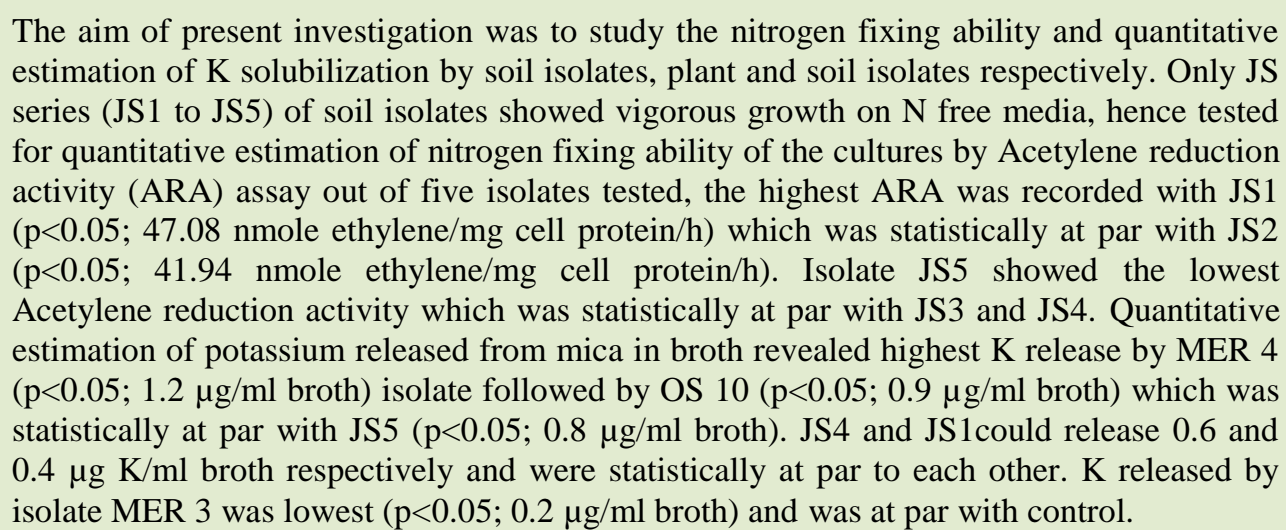 } \\
\hline Keywords & \\
\hline $\begin{array}{l}\text { Nitrogen fixing } \\
\text { ability, K } \\
\text { solubilization, } \\
\text { ARA, Mica. }\end{array}$ & \\
\hline Article Info & \\
\hline $\begin{array}{l}\text { Accepted: } \\
\text { 19 October } 2017 \\
\text { Available Online: } \\
\text { 10 December } 2017\end{array}$ & \\
\hline
\end{tabular}

\section{Introduction}

Though a variety of nitrogen fixing bacteria like Acetobacter, Arthrobacter, Azoarcus, Azospirillum, Azotobacter, Bacillus, Beijerinckia, Derxia, Enterobacter, Herbaspirillum, Klebsiella, Pseudomonas and Zoogloea have been isolated from the rhizosphere of various crops (Barraquio et al., 2000; James et al., 2000), interest in the beneficial nitrogen fixing growth promoting rhizobacterial-plant association has increased recently due to their potential use as biofertilizers (Vessey, 2003). Plant associated nitrogen-fixing bacteria have been considered as one of the possible alternatives for inorganic nitrogen fertilizer for promoting plant growth and yield (Ladha and Reddy, 2000). A wide range of bacteria namely Pseudomonas,

Burkholderia, Acidothiobacillus ferrooxidans, Bacillus mucilaginosus, B. edaphicus, B. circulans and Paenibacillus sp. had been reported to release potassium in accessible form potassiumbearing minerals in soils (Sheng, 2006 and Lin et al., 2002). These potassium solubilizing bacteria (KSB) were found to dissolve potassium, silicon and aluminum 
from insoluble K-bearing minerals such as micas, illite and orthoclases, by excreting organic acids which either directly dissolved rock $\mathrm{K}$ or chelated silicon ions to bring $\mathrm{K}$ into the solution (Aleksandrov et al., 1967; Ullaman et al., 1996 and Bennett et al., 1998). Inoculation with potassium solubilizing bacteria had been reported to exert beneficial effects on growth of wheat (Sheng and He, 2006). Similarly, inoculation of maize and wheat plants with Bacillus mucilaginosus, Azotobacter chroococcum and Rhizobium resulted in significant higher mobilization of potassium from waste mica, which in turn acted as a source of potassium for plant growth (Singh et al., 2010).

For optimum crop production, soil solution and exchangeable $\mathrm{K}$ need to be replenished continually with $\mathrm{K}$ releasing by nonexchangeable $\mathrm{K}$ through weathering of $\mathrm{K}$ resources such as micas and feldspars (Sparks and Huang, 1985) or by addition of $\mathrm{K}$ fertilizers. Therefore, the application of $\mathrm{K}$ solubilizing bacteria is a promising approach for increasing $\mathrm{K}$ availability in soils cultivation of more $\mathrm{K}$ demand crops (Zahar et al., 1984; Vandevivaea et al., 1994 and Barker et al., 1998). Hence, the present investigation was undertaken to study the nitrogen fixing ability of diazotrophic soil isolates and quantitative estimation of $\mathrm{K}$ solubilization by soil and plant isolates.

\section{Materials and Methods}

The present investigation conducted during rabi season of 2016-17 at Research Farm of ICAR-IISS, Bhopal to study the "The Study of Nitrogen fixing ability of soil isolates and quantitative estimation of $\mathrm{K}$ solubilization by soil and plant isolates". The material used and methods adopted during the course of experimentation in the field and laboratory are described in brief as under following heads.

\section{Glasswares and media sterilization}

All media were autoclaved at 15 psi (1.06 $\mathrm{kg} / \mathrm{cm}^{2}$ ) pressure for 20 minutes. Antibiotics, tryptophan stock were filter sterilized by using $0.22 \mu \mathrm{m}$ disposable syringe filters. Glasswares used were sterilized in hot air oven for 2 hours at $180^{\circ} \mathrm{C}$.

\section{Isolation of bacteria from soil}

For isolation of aerobic nitrogen fixing bacteria, $5 \mathrm{~g}$ composite soil sample was added to flask containing $100 \mathrm{ml}$ Jensen's $\mathrm{N}$-free broth. The flask was incubated at $30 \pm 2^{\circ} \mathrm{C}$ in incubator-shaker at $200 \mathrm{rpm}$ for 48 hours. After 48 hours, $10 \mathrm{ml}$ of inoculums was inoculated in fresh $100 \mathrm{ml}$ Jensen's N-free broth and incubated as mentioned above. The process was repeated five times to eliminate all the other microbes not capable of fixing atmospheric nitrogen under aerobic condition. From last transferred flask, serial dilution was prepared up to $10^{-7}$ dilution and $100 \mu \mathrm{l}$ of inoculum was spread plated on Jensen's Nfree Agar media.

\section{Isolation of endophytic bacteria from maize root}

Isolation of endophytic bacteria from maize root was done by washing it thoroughly in running water. The excised roots were surface sterilized by placing 10 grams fresh root in $5 \%$ sodium hypochlorite for 10 minutes and then in $70 \%$ ethanol for 2 minutes. The roots were thoroughly washed with sterile distilled water thrice. Ten $\mathrm{ml}$ of sterile water was added to the surface sterilized roots and shaken for 10 minutes vigorously to check the sterility of rhizoplane. From this suspension, $100 \mu \mathrm{l}$ aliquot was spread plated on nutrient agar media. Further, the surface sterilized roots were crushed with sterilized mortar and pestle in $9 \mathrm{ml}$ physiological saline $(0.85 \%$ sodium chloride solution). From this sap, 
serial dilution was prepared and $100 \mu \mathrm{l}$ inoculum was again spread plated on nutrient agar plates. Three replications were maintained for each dilution and the plates were incubated at $28^{\circ} \mathrm{C}$ for 48 hours. Morphologically distinct colonies were purified by repeated streaking on nutrient agar media and were used for further study.

\section{Aerobic nitrogen fixation}

Nitrogen free Jensen's agar media was used for detection of free living aerobic nitrogen fixers. Media was poured in sterilized petriplates.

After solidification, grids were prepared on the lower surface of petriplate. Isolates were washed in physiological saline by centrifugation to remove traces of nitrogen that it could have received from earlier media. All the isolates were spot inoculated in their respective grids and incubated at $28 \pm 2{ }^{\circ} \mathrm{C}$ for 2 days. Isolate showing growth were further streaked on Jensen's media to conform the nitrogen fixing ability.

Acetylene Reduction Activity (ARA) was used for determination of nitrogen fixing ability of the isolates. Ten $\mathrm{ml}$ of Jensen's broth was inoculated with $200 \mu \mathrm{l}$ of previously grown cultures showing growth on Jensen's agar plate. The inoculated tubes were incubated in an incubator at $28+2^{\circ} \mathrm{C}$ for 4 days. After that cotton plugs were aseptically replaced with sterile subaseals. Ten percent of the airspace in the tube was replaced with acetylene and these were further incubated for 24 hrs.

At the end of incubation period, nitrogen fixation ability of the culture was determined by acetylene reduction activity (ARA) by the method of Hardy et al., (1973) using a gas chromatograph (Nucon 5765 model) with FID detector having Porapak $\mathrm{N}$ column. The carrier gas was Helium. The operating conditions were: Column temperature: $75^{\circ} \mathrm{C}$, Injector temperature: $110^{\circ} \mathrm{C}$, and Detector temperature: $110^{\circ} \mathrm{C}$. Three replications per treatment and appropriate uninoculated controls were maintained. The results were expressed in terms of nmoles of ethylene/mg cell protein $/ \mathrm{h}$.

\section{Potassium solubilization by bacterial isolates}

For quantitative determination of potassium solubilization from mica, $100 \mathrm{ml}$ of sterilized Aleksandrov media containing mica as mineral potash source were inoculated with 2 $\mathrm{ml}$ of bacterial suspension (approx $10^{8}$ $\mathrm{cfu} / \mathrm{ml}$ ) positive for $\mathrm{K}$ solubilization based on plate assay in $250 \mathrm{ml}$ Erlenmeyer flask. The flasks were and incubated at $30 \pm 2^{\circ} \mathrm{C}$ and 200 rpm for 7 days in an incubator-shaker (makeKuhner). For each isolate three flasks were inoculated. After 7 days, each flask was checked for potassium release by flame photometry. The suspension was centrifuged at 10,000 rpm for $10 \mathrm{~min}$ and supernatant was retained. $1 \mathrm{ml}$ of supernatant was taken in 25 $\mathrm{ml}$ volumetric flask and volume was made to $25 \mathrm{ml}$ with distilled water and mixed thoroughly. After that the solution was fed to flame photometer for estimating $\mathrm{K}$ ( $\mathrm{Hu}$ et al., 2006; Saiyad et al., 2015).

\section{Statistical analysis}

Statistical analyses were carried out through one-way analysis of variance (ANOVA) and the mean of treatments were compared according to Fisher's multiple comparison tests. Least significant difference (LSD) was calculated at $\mathrm{p}<0.05$ using statistical package of SAS. Multivariate analysis of PGP attributes was performed using Principle Component Analysis and clustering of isolates based on Euclidean distance method was calculated with SAS statistical package. 


\section{Results and Discussion}

\section{Nitrogen fixation}

All the 32 isolates were spot inoculated on nitrogen free media in grid prepared on the plates. Except JS series cultures that were obtained through Enrichment Technique on $\mathrm{N}$-free media, only few isolates showed growth on $\mathrm{N}$-free media which upon restreaking on $\mathrm{N}$-free media, failed to grow, indicating inability of these cultures to grow in absence of combined nitrogen (Table 1). Only JS series culture showed vigorous growth on $\mathrm{N}$ free media, hence JS series cultures were tested for quantitative determination of nitrogen fixing ability of the cultures by Acetylene reduction activity (ARA) assay. Out of five isolates tested, the highest ARA was recorded with JS1 $(\mathrm{p}<0.05$; 47.08 nmole ethylene/mg cell protein $/ \mathrm{h}$ ) which was statistically at par with JS2 $(\mathrm{p}<0.05 ; 41.94$ nmole ethylene/mg cell protein/h). Isolate JS5 showed the lowest Acetylene reduction activity which was statistically at par with JS3 and JS4 (Table 1).

\section{Potassium solubilization ability}

Quantitative estimation of potassium released from mica in broth revealed highest $\mathrm{K}$ release by MER 4 ( $\mathrm{p}<0.05 ; 1.2 \mu \mathrm{g} / \mathrm{ml}$ broth) isolate followed by OS 10 ( $\mathrm{p}<0.05 ; 0.9 \mu \mathrm{g} / \mathrm{ml}$ broth) which was statistically at par with JS5 ( $<<0.05 ; 0.8 \mu \mathrm{g} / \mathrm{ml}$ broth). JS4 and JS1could release 0.6 and $0.4 \mu \mathrm{g} \mathrm{K} / \mathrm{ml}$ broth respectively and were statistically at par to each other. $\mathrm{K}$ released by isolate MER 3 was lowest ( $<<0.05 ; 0.2 \mu \mathrm{g} / \mathrm{ml}$ broth) and was at par with control. Decline in $\mathrm{pH}$ at the end of incubation period was also recorded with inoculation of isolates in media. The lowest $\mathrm{pH}$ was noted with MER4 (4.1) followed by JS4 (4.2), JS1 (4.3), JS5 (4.42), OS10 (4.7) and MER3 (5.32). Control broth could maintain neutral $\mathrm{pH}$ (Table 2).

Table.1 Acetylene reduction activity (ARA) of microbes isolated from soil

\begin{tabular}{cc}
\hline Isolates & ARA (n moles ethylene/mg protein/h) \\
\hline JS1 & $47.08 \mathrm{a}$ \\
JS2 & $41.94 \mathrm{a}$ \\
JS3 & $22.92 \mathrm{~b}$ \\
JS4 & $26.37 \mathrm{~b}$ \\
JS5 & $20.72 \mathrm{~b}$ \\
LSD $(\mathbf{0 . 0 5})$ & 6.2 \\
\hline
\end{tabular}

Table.2 Quantitative estimation of potash solubilization by selected isolates

\begin{tabular}{ccc}
\hline Isolates & K released $(\boldsymbol{\mu g} / \mathbf{m l}$ broth $)$ & $\mathbf{p H}$ \\
\hline Control & $0.1 \mathrm{~d}$ & 7.2 \\
JS1 & $0.4 \mathrm{c}$ & 4.3 \\
JS4 & $0.6 \mathrm{c}$ & 4.2 \\
JS5 & $0.8 \mathrm{~b}$ & 4.42 \\
OS10 & $0.9 \mathrm{~b}$ & 4.7 \\
MER3 & $0.2 \mathrm{~d}$ & 5.32 \\
MER4 & $1.2 \mathrm{a}$ & 4.1 \\
LSD $(\mathbf{0 . 0 5})$ & 0.21 & \\
\hline
\end{tabular}




\section{Growth on N-free Jensen's medium}

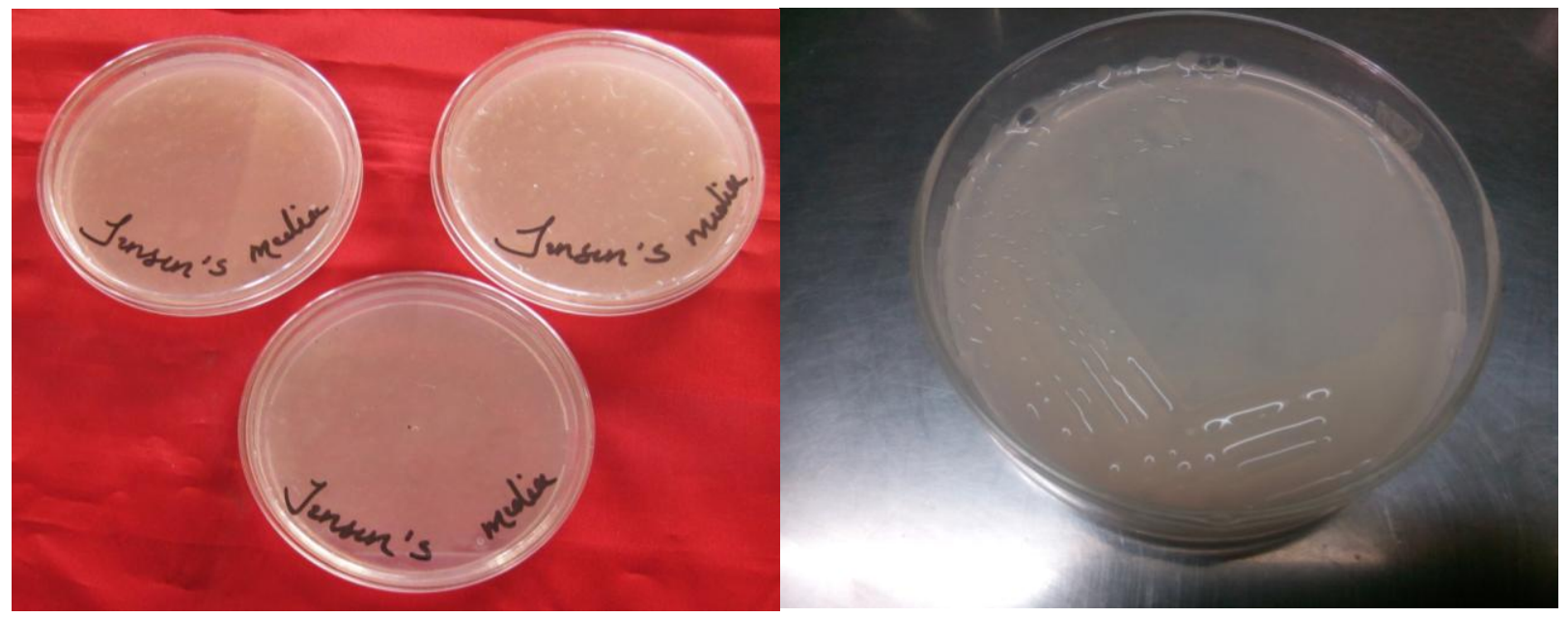

Fig.1 Acetylene reduction activity of cultures

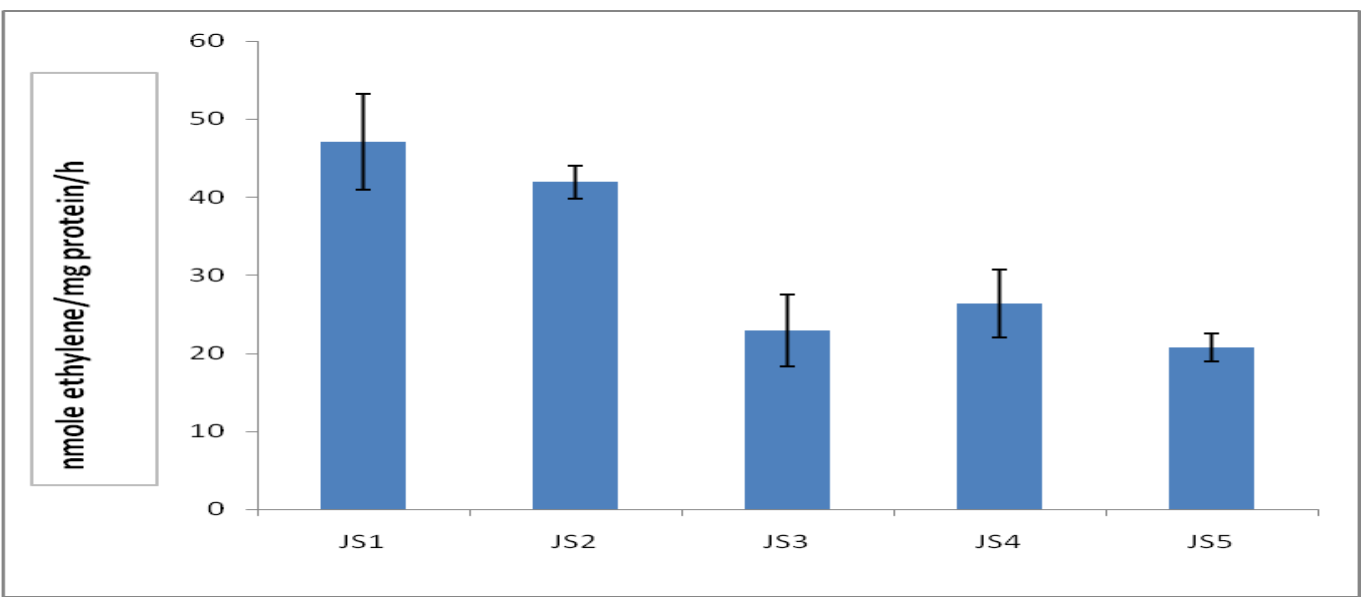

Fig. $2 \mathrm{~K}$ released $(\mu \mathrm{g} / \mathrm{ml}$ culture broth)

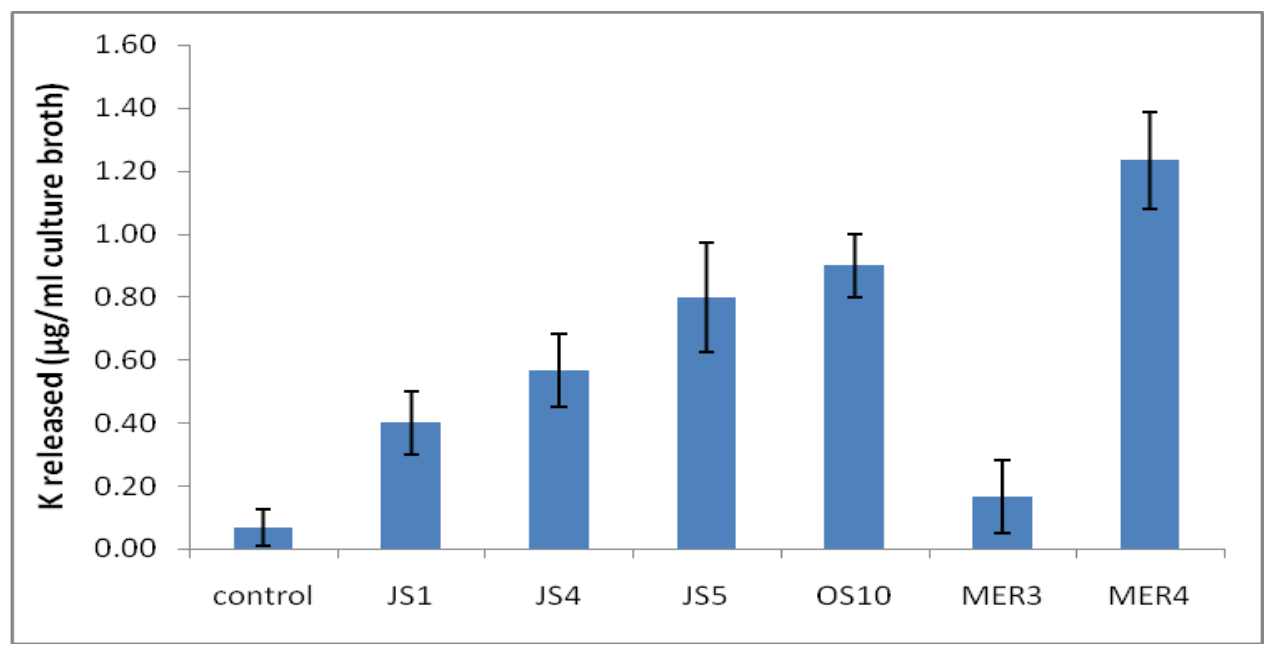


Over all, out of 32 isolates, only five isolates (JS1 to JS5) which was isolated by enrichment techniques were able to fix atmospheric nitrogen. Highest ARA was recorded with JS1 and JS 2 culture (Fig. 1). None of the other isolates were capable of nitrogen fixation. Some microorganisms fix atmospheric nitrogen to ammonia and make it available to the plant. Such microbes are found to possess enzyme nitrogenase for nitrogen fixation. Free living non-symbiotic aerobic nitrogen fixers are widely distributed in arable soils. Though non-symbiotic nitrogen fixation has a great agronomic significance, a major limitation that it faces is the availability of carbon and energy source for the energy intensive nitrogen fixation process (Saharan and Nehra, 2011) particularly under tropical soil which are inherently poor in organic matter content. The use of bio-fertilizer such as $\mathrm{N}_{2}$ (nitrogen) fixing bacteria and beneficial micro-organism can reduce chemical fertilizer applications and consequently lower production cost.

Quantitative estimation also revealed $1.2 \mu \mathrm{g} / \mathrm{ml}$ culture broth (having $10^{7}$ cell $/ \mathrm{ml}$ ) of $\mathrm{K}$ released, highest among all the positive isolates (Fig. 2). The drop in $\mathrm{pH}$ of media was suggestive of possible mechanism of $\mathrm{K}$ solubilization by the isolates.

A negative correlation (-0.70) between $\mathrm{pH}$ and K-released in media was observed indicating production of acids leads to solubilization of mineral and release of $\mathrm{K}$ in the media. Production of carboxylic acids like Lactic acid, Acetic acid and Gluconic acid in potash solubilizing media was also reported by Saiyad et al., (2015), confirming our findings. In present investigation four endophytic isolates were obtained from maize roots. These isolates were caplable of mobilizing potash from mica and $24.227 \mu \mathrm{g} / \mathrm{ml}$ (containing $10^{7}$ cells $/ \mathrm{ml}$ ) in Potassium solubilizing media (MER3).
Conducted study concluded that out of five isolates tested, the highest ARA was recorded with JS1 ( $p<0.05 ; 47.08$ nmole ethylene/mg cell $\mathrm{protein} / \mathrm{h}$ ) which was statistically at par with JS2 ( $\mathrm{p}<0.05 ; 41.94$ nmole ethylene/mg cell protein $/ \mathrm{h})$. Quantitative estimation of potassium released from mica in broth revealed highest $\mathrm{K}$ release by MER 4 ( $\mathrm{p}<0.05 ; 1.2 \mu \mathrm{g} / \mathrm{ml}$ broth).

\section{References}

Aleksandrov, V. G., Blagodyr, R. N. and Live, I. P.1967. Liberation of phosphoric acid from apatite by silicate bacteria. Mikrobiyolzh. (Kiev). 29: 111114.

Barker, W. W., Welch, S. A., Chu, S. and Banfield, J. F.1998. Experimental observations of the effects of bacteria on aluminosilicate weathering. Am Mineral. 83: 1551-1563.

Barraquio,

W.L., Segubre,E.M., Gonzalez,M.S., Ve rma, S.C.,James, E.K., Ladha, J.K. and TripathiA.K. 2000. Diazotrophic enterobacteria: what is their role in rhizosphere of rice?

Bennett, P. C., Choi, W. J. and Rogera, J. R. 1998. Microbial destruction of feldspars. Mineral Mngt. 8(62A): 149150.

Hardy, R. W. F., Burns, R. C., Holsten, R. D. 1973.Application of acetylene-ethylene assay for measurement of nitrogen fixation.Soil. Biol. Biochem. 5:47-81.

$\mathrm{Hu}$, X.F., Chen, J. and Guo, J.F. 2006. Two phosphate and potassium solubilizing bacteria isolated from Tiannu mountain, Zhejiang, China. World Journal of Microbiology and Biotechnology. 22:983-990.

James, E.K., P. Gyaneshwar, W.L. Barraquio, N. Mathan and J.K. Ladha 2000. Endophytic diazotrophs associated with rice. 
Ladha, J.K., Reddy, P.M., 2000. The quest for nitrogen fixation in rice. Proceedings of the Third Working Group Meeting on Assessing Opportunities for Nitrogen Fixation in Rice, 9-12 Aug. 1999. IRRI, Los Banos, Laguna, Philippines, 354pp.

Ladha,J.K. andReddy, P.M. (Eds.), The Quest for Nitrogen Fixation in Rice, Los Banos, Philippines (2000), pp. 119-140

Lin, Q. M., Rao, Z. h., Sun, Y. X., and Xing, L. I. 2002. Identification and practical application of silicate- dissolving bacteria. Agric. Sci. China. 1: 81-85.

Saharan, B.S. and Nehra, V. 2011. Plant Growth Promoting Rhizobacteria: A Critical Review. Life Sciences and Medicine Research. 2011: LSMR-21.

Saiyad, Sajidmohammad A., Jhala, Yogeshvari K. and Vyas, R. V. 2015. Comparative efficiency of five potash and phosphate solubilizing bacteria and their key enzymes useful for enhancing and improvement of soil fertility. International Journal of Scientific and Research Publications. 5(2):1-6.

Sheng, X. F. 2006. Growth promotion and increased potassium uptake of cotton and rape seed by a potassium releasing strain of Bacillus edaphicus. Soil Biol. Biochem. 37(1): 1918-1922.
Singh, G., Biswas, D. R. and Marwah, T. S. 2010. Mobilization of potassium from waste mica by plant growth promoting rhizobacteria and its assimilation by maize (Zea mays L.) and wheat (Triticum aestivum L.). J. Plant Nutrit. 33: 1236-1251.

Sparks, D. L. and Haung, P. M. 1985. Physical chemistry of soil potassium. In potassium in Agriculture (Ed.) Munson, R. D. American Soc. Agron. J. pp. 201276.

Ullaman, W. J., Kirchman, D. L. and Welch, W. A. 1996. Laboratory evidence by microbially mediated silicate mineral dissolution in nature. Chem. Geol. 132: 11-17.

Vandevivaea, P., Welch, S. A., Ullman, W. J. and Kirchman, D. L. (1994). Enhanced dissolution of silicate minerals by bacteria at near-neutral pH. Microb. Ecol. 27(3): 241-251.

Vessey, J.K. 2003. Plant growth promoting rhizobacteria as biofertilizers.Plant Soil. 255: 571-586

Zahar, M. K., Monib, M., Abdel-Al ShI and Heggo, A. 1984. Significance of soil inoculation with silicate bacteria. Zentralbl Mikrobiol., 139(5): 349-357.

\section{How to cite this article:}

Diksha Vishwakarma, J.K. Thakur and Gupta, S.C. 2017. A Study on Nitrogen Fixing Ability of Soil Isolates and Quantitative Estimation of K Solubilization by Soil and Plant Isolates. Int.J.Curr.Microbiol.App.Sci. 6(12): 2641-2647. doi: https://doi.org/10.20546/ijcmas.2017.612.305 